Nuntius Antiquus, Belo Horizonte, v. 12, n. 1, p. 187-213, 2016

\title{
Helen's semiotic body: ancient and modern representations
}

\section{O corpo semiótico de Helena: representações antigas e modernas}

Konstantinos P. Nikoloutsos

Saint Joseph's University

Philadelphia, PA - USA

konstantinos.nikoloutsos@sju.edu

\begin{abstract}
The paper draws on theoretical work on the representation of the female body as an object of the male gaze in modern narrative, in order to decode and analyze Helen's portrayal as a physical vacuum in ancient literature. I argue that the negation of Helen's corporeality emphasizes the semiotic duality of her body, allowing it to be deployed both as a sign and as a site for the inscription of signs. The paper, then, proceeds to show how Helen's Iliadic depiction has provided the eighteenth-century philosopher Edmund Burke with a rhetorical platform upon which to theorize the aesthetic dichotomy between the beautiful and the sublime. I close my analysis by illustrating how the eclecticism, compromises, and pastiches that inform Helen's cinematic recreations find a parallel in, and thus perpetuate, ancient pictorial techniques.
\end{abstract}

Keywords: Helen; Iliad; Edmund Burke; female body and male gaze; Homer on film.

Resumo: Este artigo baseia-se em um trabalho teórico sobre a representação do corpo feminino como um objeto do olhar masculino na narrativa moderna, a fim de decodificar e analisar o retrato de Helena como um vácuo físico na literatura antiga. Defendo que a negação da corporalidade de Helena enfatiza a dualidade semiótica de seu corpo, permitindo que este seja apresentado tanto como um signo quanto 
como um lugar para a inscrição de signos. O artigo, então, mostra, na sequência, como a representação de Helena na Ilíada proporcionou ao filósofo Edmund Burke, do século XVIII, uma plataforma retórica sobre a qual teorizar a dicotomia estética entre o belo e o sublime. Encerro minha análise ilustrando como os ecletismos, concessões e pastiches que configuram as recriações cinematográficas de Helena encontram um paralelo com técnicas pictóricas antigas e assim as perpetuam.

Palavras-chave: Helena; Ilíada; Edmund Burke; corpo feminino e olhar masculino; Homero no cinema.

Artigo recebido em 12 de novembro de 2015 Aprovado para publicação em 8 de dezembro de 2015

\section{Fragmenting Helen}

A major paradox characterizes Helen's depiction in ancient Greek literature. Although she is celebrated as the epitome of physical perfection, this fundamental attribute is never described in a concrete and detailed manner. Helen is one of the most recognizable names of classical myth. Her influence is far-reaching in terms of both chronology and genres. From the archaic to the end of the classical period, she appears repeatedly in literary works as diverse as epic, lyric, tragedy, historiography, philosophy, rhetoric, and even comedy. Yet, no matter how many times the legend of Helen is revisited in classical antiquity, whether independently or as part of the saga of the Trojan War, her dazzling silhouette evades textual representation and exists only in the form of a shadow. Helen's exceptional beauty is always a given. Its components, however, are invisible and kept firmly outside the realm of authorial discourse. Like the Cartesian body per Francis Barker's muchquoted statement, Helen's figure as a whole is not to be found anywhere in language; "it is given to discourse as an object... but it is never of languaging in its essence" (BARKER, 1995, p. 90). 
Helen is the embodiment of supreme physical qualities. She

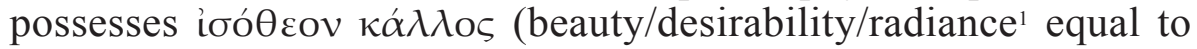
that of gods), as the late fifth-century sophist Gorgias of Leontini emphasizes in the proem of his Encomium of Helen (4) - a speech he wrote with the intention to restore the tarnished reputation of Homer's heroine and defend her for abandoning her husband and betraying her country for the sake of a Trojan man who was seen as a "barbarian" in post-Homeric antiquity. ${ }^{2}$ Helen, as Gorgias points out, is not an ordinary woman. She is the product of the union of Zeus, the highest-ranking Olympian deity, with Leda, wife of the Spartan king Tyndareus. ${ }^{3}$ She is also Zeus' only daughter through a mortal mistress, and that makes her unique in the mythic world (BLONDEL, 2013, p. 29). As such, Helen surpasses all other heroines in attraction and causes men to fall under her spell and experience uncontrolled ǩows (love). However, her legendary looks, with which she seduced Paris when he arrived at Sparta, leading to her elopement that ignited the longest and deadliest war in classical myth, remain an enigma and are never itemized in

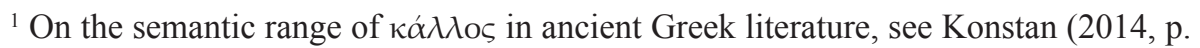
31-61).

${ }^{2}$ In the Iliad there is little distinction between the Trojans and the Achaeans in cultural terms. The dichotomy originated in Athenian tragedy and the visual arts of the post-Persian Wars period, when all the non-Greek inhabitants of Asia Minor and the East in general were labeled collectively as "barbarians." See Hall (1989, p. 101-159, 211-223).

${ }^{3}$ In his own epideictic speech (10.38), Isocrates also attributes - albeit not so explicitly as Gorgias - Helen's superlative beauty to her divine parenthood. The Iliad conveys a more complicated picture of Helen, both mortal and above the mortals. In Book III (199, 418), she is called $\Delta$ iò $\dot{\varepsilon} \kappa \gamma \varepsilon \gamma \alpha \cup \tilde{L} \alpha$ (born of Zeus) - the same formulaic epithet is used

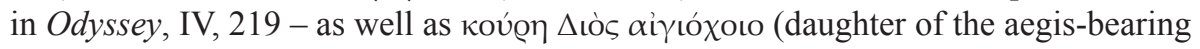
Zeus, Iliad, III, 426). As Edmunds (2015, p. 194) points out, in all these instances "Homer is the speaker. No character in the Iliad refers to Helen as daughter of Zeus, and, for that matter, no character seems even to be aware that she is the daughter of

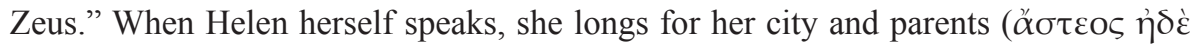
$\tau$ тоќ $\omega v$, Iliad, III, 140), a clear reference to Tyndareus and Leda. As Blondell (2013, p. 55) notes, this is "a humanizing detail that locates her [Helen] securely in the mortal world." This is also the case with Iliad, III, 414-417, where Aphrodite threatens to lift Helen's comeliness and make her protégé hateful among the Greeks and Trojans as a punishment for her persisting insubordination. See Austin (1994, p. 10). 
surviving textual sources in ways that permit the reconstruction of a plausible, coherent image.

Helen's body is both the agent and the object of male desire in classical myth. Perfection of face and form is Helen's defining quality that makes her a coveted trophy for unmarried heroes. It is because of the $\kappa \lambda \dot{\text { os }}$ (renown) of her external appearance that her suitors sought to make her their wife, although they had not seen her in person, as we hear in the Catalogue of Women (frs. 199.1-9; 204.56-64) - an epic poem of uncertain authorship that has been traditionally attributed to Hesiod. ${ }^{4} \mathrm{Her}$ irresistible allure gives Helen the power, and an excuse, to violate the gender norms and moral protocols of Greek patriarchal social order and act in ways that establish her as the paradigm of female transgression. Without her beauty, Helen would not have played such a prominent role in the story of the Trojan War. Her body is key to the unfolding of the legend and its symbolic system. In linguistic terms, it is both the signifier (an instigator of action and a catalyst for the production of meaning) and the signified (a site upon which manly values and the heroic code of honor are inscribed, negotiated, and validated).

The totemic importance of Helen's body is prima facie 5 underscored in Faust's famous apostrophe to the summoned shade of Helen ("that peerless dame of Greece," V.i.13-14, 20) in Christopher Marlowe's The Tragical History of the Life and Death of Doctor Faustus, one of the most controversial plays of the Elizabethan era:

Was this the face that launched a thousand ships

And burnt the topless towers of Ilium?

- Sweet Helen, make me immortal with a kiss:

Her lips suck forth my soul, see where it flies! (V.i.96-99)

\footnotetext{
${ }^{4}$ For a discussion of the fragments, see, e.g., Ziogas (2013, p. 20-28); Ormand (2014, p. 191-193).

${ }^{5}$ When read outside of its context, the passage gives the false impression that it conveys Faust's awed reaction to Helen's disarming beauty. However, as Maguire (2009, p. 160) inter alios notes, "the lines are addressed not to Helen of Troy but a devil impersonating Helen, and Faustus is responding to, at best, a clever illusion, at worst, a cheap trick; that is, he is deceived or self-deceiving."
} 
Marlowe's protagonist, appropriated from a popular German legend, locates Helen's erotic powers on her countenance. From an intertextual perspective, Faust echoes the warning that Hecuba gives to Menelaus about Helen's lethal magnetism in Euripides' tragedy The Trojan Women:

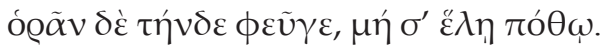

$\alpha$

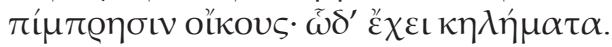

But avoid looking at her, lest she might seize you with longing.

For she captures the eyes of men, she destroys cities,

She burns down houses. She possesses such charms. ${ }^{6}$

Faust identifies Helen via her face, as if he were looking at a portrait. This metonymic representation of Helen's silhouette exemplifies a common pattern in modern narrative: the fragmentation of the female body into parts when it becomes the focal point of the male gaze. Fetishistically invested physical details captivate the eye of the male onlooker and serve figuratively as symbols for the female body as a whole (pars pro toto) which - to the reader's frustration - is denied entry into the authorial discourse. As Peter Brooks explains about this representational strategy used frequently in novels of the nineteenth century, which are (in their majority) written by male authors for an audience that consists primarily of men and does not grant female readers a dissenting perspective:

[L]iterary representations most often have a playful indirectness, naming the private body through a series of substitutions, as metonymies and metaphors... [T] he object of attention and desire... is not detailed... but rather approached by way of its phenomenal presence in the world.... (BROOKS, 1993, p. 18-19)

Since the publication of Marlowe's provocative play in 1604, Faust's aphorism has been disconnected from its context and has, in its abridged version "the face that launched a thousand ships", traveled widely across time, infusing popular culture to such a degree that it has become a very stereotypical, if not the archetypal, way of referring to

\footnotetext{
${ }^{6}$ All translations from Greek are my own.
} 
Helen in modernity. Like a folk expression or a biblical dictum, Faust's utterance, once extracted from Marlowe's text, was edited to become quotable and has been subsequently transmitted, carrying its own accrued deposit of meaning. ${ }^{\text {? }}$

As a form of mass entertainment, cinematic adaptations of the Iliad have sought to capitalize on the quasi-proverbial status that Marlowe's words have gained over time. Audiences, of course, may not always be able to recognize the source text from which the line is drawn, but aural familiarity with it enables the mental creation of a larger web of references. For example, The Face That Launched a Thousand Ships is the title chosen in the U.K. for the 1955 theatrical release of a Hollywood film that, like many runaway productions of the postwar era, was shot at low cost in Rome's Cinecittà Studios and premiered in Italy on 24 December 1954 under the title L'Amante di Paride (The Lover of Paris). ${ }^{8}$ The picture was planned as a star vehicle for Hollywood glamour queen Hedy Lamarr ${ }^{9}$ who co-financed the venture with producer Victor Pahlen and played the lead role in the "Helen of Troy" segment of the film that survives today in a severely truncated version as The Love of

${ }^{7}$ The following comment by the columnist and television personality Dorothy Kilgallen illustrates the extent to which Marlowe's words have permeated modern popular culture. In appraising Hedy Lamarr's typecasting as a raven-haired femme fatale, which reached its apogee in her incarnation of the titular seductress in Samson and Delilah (dir. Cecil DeMille, 1949), the highest-grossing picture of its year, Kilgallen wrote in The American Weekly (3 February 1952, p. 18): “Lamarr became this generation's version of the Vamp - a synonym for the woman who launches ships, wrecks homes and sends countless men to glory or to doom." Quoted from Negra (2001, p. 103). Another comment, this time about supermodel Cindy Crawford, also illustrates the currency that Marlowe's line has gained in our days and its deployment as the canonical definition of female beauty. In The New York Times Style Magazine (25 October 2015, p. 72), Crawford is labeled as "the face that launched a thousand beauty marks."

${ }^{8}$ On the history of the film's troubled production, see, e.g., Lamarr (1966, p. 216-221); Krohn (2009, p. 182-183); Barton (2010, p. 189-192); Shearer (2010, p. 275-280); Isenberg (2014, p. 227-229).

${ }^{9}$ On the ways in which the film seeks to capitalize on Lamarr's status as a silver screen queen of glamour and anachronistically equates Greek royalty with Hollywood royalty, see Nikoloutsos (2015, p. 74-81). 
Three Queens. ${ }^{10}$ Penned by a group of writers, the screenplay - which is a fusion of ancient texts, replete with anachronistic clichés and soaked in the language of melodrama - pays tribute to Marlowe. When Paris (Massimo Serato) receives the invitation to fight Menelaus (Robert Beatty) in a duel with Helen as the victor's prize, he declines, claiming that his fighting technique is different from that of his opponent: he is good at throwing the javelin from a racing chariot, whereas Menelaus knows how to use the sword and the spear, which gives him a clear advantage in a hand-to-hand combat. Hearing his response, Oenone (Cathy O'Donnell), a Trojan maid with whom Paris was in love prior to his voyage to Sparta, ${ }^{11}$ intervenes and urges him to bear the responsibility of his reckless decision to abduct Helen. As the camera zooms on the Spartan queen, Oenone prophesizes Paris' death, crying out a slightly modified version of Faust'swords: "You know the truth, Paris. This was the face that launched a thousand ships and burned the topmost towers of Troy."

${ }^{10}$ The Love of Three Queens is the title of the 94-minute footage included in a DVD that was released in USA on 16 January 2014 under the title Loves of Three Queens.

${ }^{11}$ Oenone, a nymph who was also a seer and healer, makes her debut in Greek literature of the Hellenistic period, although Palmer (1898, p. 315) suspects that her story is earlier. Paris met her on Mount Ida, where as a young shepherd he tended his cattle. The two of them fell in love and lived together as a couple, until Paris left for Sparta, following his Judgment. Oenone had previously prophesized that Paris would discover himself to be the son of Trojan king Priam and that he would abandon her for another woman. During the siege of Troy, the wounded Paris, using their son Corythus as a mediator, begged Oenone to save his life, but she refused. When she reconsidered, she rushed to his side only to find out that he was dead. For a list of Greek texts featuring Oenone, see Fulkerson, 2005, p. 56, n. 48.

${ }^{12}$ It is worth noting the two words from Marlowe's famous aphorism that are substituted when put in Oenone's mouth: topless (it nowadays carries sexual connotations and is used to denote a woman's garment that has no cover for the breasts) and Ilium (it would confuse the average viewer who does not know that it is an alternate name for Troy). 
194 Nuntius Antiquus, Belo Horizonte, v. 12, n. 1, p. 187-213, 2016

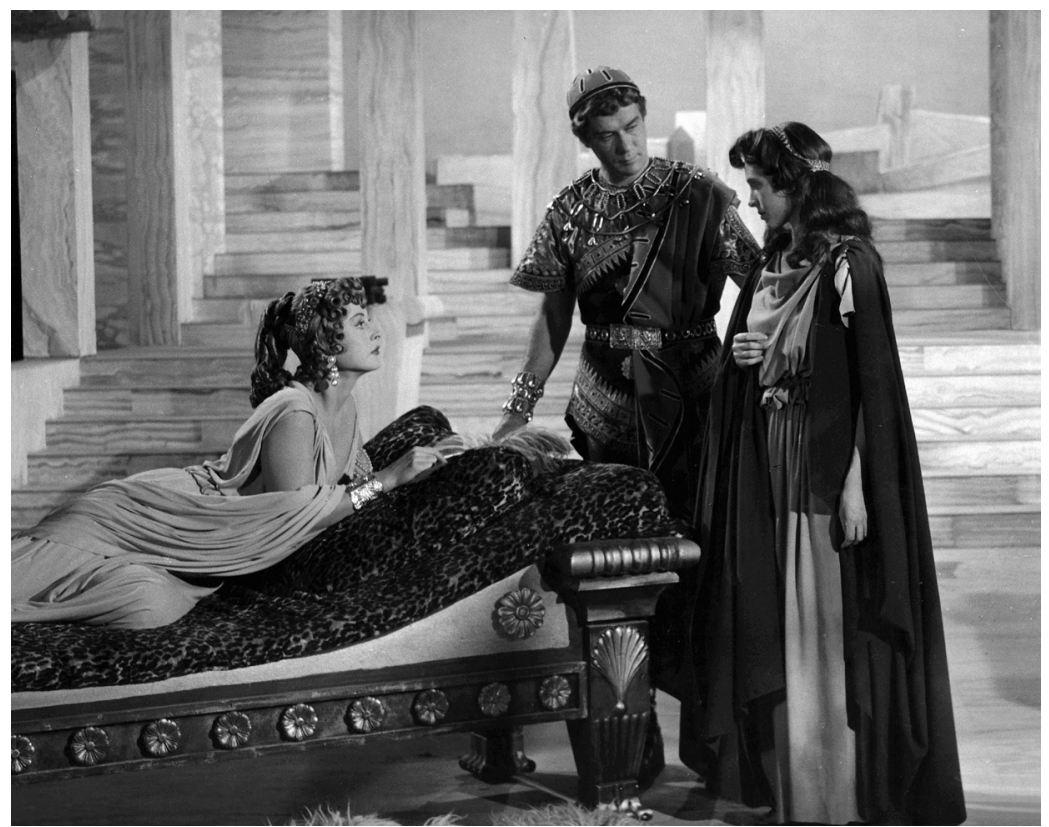

FIGURE1: Helen (Hedy Lamarr), Paris (Massimo Serato), and Oenone (Cathy O'Donnell) in The face that launched a thousand ships (dir. Marc Allegret, 1953).

Credit: CINO DEL DUCA/PCE/THE KOBAL COLLECTION.

By contrast, Hugh Gray, an Oxonian with a degree in Classics who was hired by Warner Brothers to write the script for Helen of Troy (dir. Robert Wise, 1956), the first spectacular filmed in CinemaScope that is set in Greek antiquity, avoided the inclusion of Marlowe's clichéd line, knowing that it is an anachronism. Although it drew on a variety of ancient works, Greek as well as Roman, ${ }^{13}$ Gray's screenplay does betray the impact of Faust's words in modern popular culture. When Menelaus finds out that Helen ran away with Paris and declares war against Troy, Gray put the following words in the mouth of Homer's hero:

\footnotetext{
${ }^{13}$ Gray's request to the research department of Warner Brothers included three tragedies by Euripides (Helen, Trojan Women, and Iphigenia at Aulis), two tragedies by Seneca (Trojan Women and Agamemnon), Shakespeare's Troilus and Cressida, and Juvenal's Satires in Latin. See Eldridge (2006, p. 142-143).
} 
Such an expedition shall be mustered as never before has sailed the wine-colored Aegean waters. Not 200 - not 500 - but 1000 ships shall be launched upon them! Troy shall see what store we put on the lovely face of Helen, and seeing that vast panoply of war - shall tremble! (ELDRIDGE, 2006, p. 143, emphasis my own)

When scenarist John Twist replaced Gray, he was astonished to discover that the script he had inherited did not feature the famous line. Although the studio's research department informed him that the quotation was not to be found anywhere in Homer's epic, Twist, nonetheless, included it in the revised screenplay. As the Trojans wake up to the sight of the Greek ships sailing against their shore, Priam (Sir Cedric Hardwicke) orders Aeneas (Ronald Lewis) to bring Paris (Jacques Sernas) and Helen (Rossana Podestà) to the walls so they can see for themselves the size of the enemy's fleet and realize the scale of the war they have caused with their thoughtless decision. When the couple arrives, the Trojan king turns to Helen and says: "See what you have brought upon us? ... [As the camera zooms on Helen and the operatic music underscores the dramatic moment of the action] The face that launched a thousand ships." 14

Although it is virtually impossible to discuss Helen's reception in the Anglophone world without recalling Marlowe's words, an attempt to retrieve Helen's facial features from ancient literature and paint a reliable portrait based on the way in which Greek authors visualized her

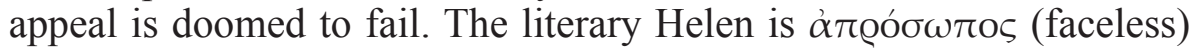
and serves as a paradigm not of specific physical traits, but of beauty as an abstract concept. ${ }^{15}$ In this paper, I propose to investigate Helen's depiction in ancient Greek poetry, paying particular attention to the Iliad. By drawing on Brooks' theories on the representation of the female body in modern narrative, I shall argue that the negation of Helen's corporeality emphasizes the semiotic duality of her body, allowing it to be deployed both as a sign and as a locus for the inscription of signs. I shall, then, proceed to show how Helen's portrayal as a physical vacuum

\footnotetext{
${ }^{14}$ On the use of Faust's aphorism in the promotion of Helen of Troy, see Winkler (2009, p. 229-230).

${ }^{15}$ As Blondell (2013, p. 2) points out, in epic poetry "beauty is presented as a substance independent of individual human features, something that the gods can apply to a person like ointment or like gilding on a work of art."
} 
in Homer's epic has provided the eighteenth-century philosopher Edmund Burke with a rhetorical platform upon which to theorize the aesthetic dichotomy between the beautiful and the sublime. I shall close this paper by surveying cinematic recreations of the Iliad in an attempt to illustrate how the eclecticism, compromises, and pastiches that inform Helen's celluloid counterparts find a parallel in, and thus perpetuate, ancient pictorial techniques - in particular Zeuxis' portrayal of Helen as a collection of body fragments, as narrated by Cicero in the proem of the second book of De Inventione.

\section{Desomatizing Helen}

In the Odyssey, the body is key to the identity of the poem's eponymous hero. When Odysseus returns to Ithaca in the guise of a beggar, his old nurse Eurycleia recognizes him, while washing his feet, by the scar that was inflicted over his knee by a boar's tusk during a hunt on Mount Parnassus in which the hero took part as a child (HOMER, Odyssey, XIX, 308-507). The mark is a necessary precondition for the inscription of Odysseus' body in Homer's poem. His scar operates in a manner similar to that of a linguistic sign: it is imprinted on his body to be read by the viewer. Through scarring, Odysseus' body becomes both an object written in the text and a "written" (i.e., marked) object - in other words a textual body. As Brooks notes about this mutual semioticization of the body and somatization of the text:

The sign imprints the body, making it part of the signifying process. Signing or marking the body signifies its passage into writing, its becoming a literary body, and generally also a narrative body, in that the inscription of the sign depends on and produces a story. (BROOKS, 1993, p. 3)

Whereas Homer devotes almost two hundred lines to narrating how Odysseus got the scar and how that diacritic mark betrayed his identity, he does not bother dwelling on any of the particulars of the most important body for the story of the Trojan War: Helen's. In the Iliad, where Helen makes her debut in Greek literature, attraction is a standard attribute of hers. This quality is acknowledged, albeit not always directly, but never itemized apart from those instances in which the poet uses formulaic language. For example, in Book III Paris suffers 
a humiliating defeat in a duel against Menelaus, at the end of which he escapes death thanks to the divine intervention of Aphrodite. The goddess envelops him in a mist and safely whisks him away from the battlefield and back to his own chamber. Helen enters the bedroom and scolds her Trojan husband for his un-heroic retreat. Paris is shockingly unashamed for his cowardice and puts the blame on the gods, offering a version of the fight that makes him immune to reproach. ${ }^{16}$ War, which he started, is not what he cares about. Captivated by Helen's radiant image, all he wants now is to have sex with her, as he admits quite bluntly:17

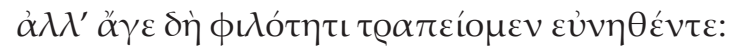

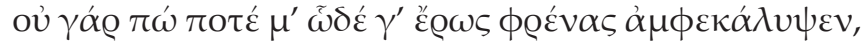

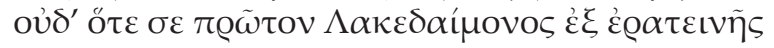

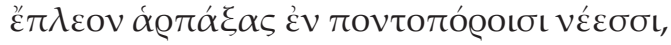

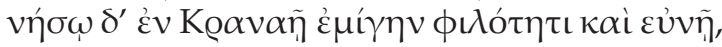

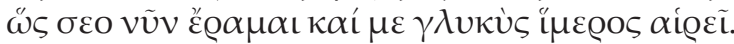

But let us enjoy ourselves by going to bed and making love.

Never before has love enwrapped my heart this way,

Not even the first time, when I abducted you

And sailed away from lovely Lacedaemon in seafaring ships

And mingled with you in the bed of love on the island of Cranae, 445

As much as I desire you now and sweet longing seizes me.

Although Paris does not fall short of words in expressing his sexual yearning upon laying eyes on Helen, "he avoids enumerating the

${ }^{16}$ On deflecting self-blame in Homer, see Scodel (2008, p. 107-114).

${ }^{17}$ Sexual arousal is a typical reaction to beauty in ancient Greek poetry (Konstan, 2014, p. 36). When the duel between Menelaus and Paris is over, Aphrodite urges Helen to go home to her wounded husband, implying that she will be overcome with sexual desire

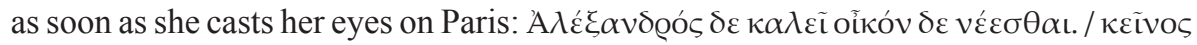

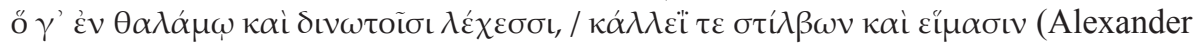
calls you to go home. He is in your chamber and on your inlaid bed, gleaming with his beauty and garments - HOMER Iliad, III, 390-392). Paris' reaction to Helen's sight in Homer (Iliad, III, 441-446) echoes Hecuba's words to her former daughter-in-law in

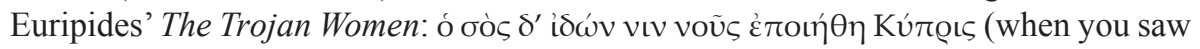
him [Paris], your mind became Aphrodite, 988). 
qualities that elicit this reaction" (BLONDEL, 2013, p. 56). ${ }^{18}$ Gazing at Helen's body makes him succumb to the powers of its charms, but what exactly her body looks like is not something that the poet feels obligated to describe. The reconstruction of Helen's beauty is, thus, left entirely to the imagination of Homer's reader - or listener in the context of public recitation. Helen is denied specificity and registered as a physical vacuum, a vehicle through which male desire is inscribed in the diegesis.

The emphasis placed on Helen's desirability is not a narrative technique limited only to the lines of the poem that pertain to the private sphere. Even when Helen violates gender protocols in Homeric society and leaves the house, the proper space for a woman in antiquity, to enter (albeit briefly) the public domain, her allure does not go unnoticed. When Helen emerges into common view, her irresistibility is established through the impact that her presence has upon her male onlookers. Thus earlier in Book III, when she arrives at the Scaean Gates in order to watch the duel between her former and current husband that will determine which of the two men will claim her as his lawful wife, the Trojan elders, who have already taken their seat, cannot fail to comment on her erotic appeal as she parades in front of them:

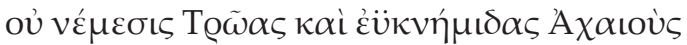

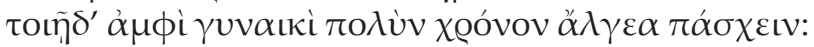

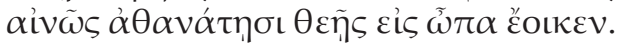

It is no cause for anger that the Trojans and well-greaved Achaeans 156 Suffer pains for a woman such as this for a long time:

She awfully resembles immortal goddesses in face.

As in the previous passage, here, too, Helen is portrayed as a fetishized object of the male gaze, deprived of individuation that could justify the collective response of her viewers to the sight of her aweinspiring silhouette. Helen joins the Trojans to watch the combat, but she is also watched. She is a spectator and simultaneously a spectacle. She is both subject and subjected to the male eye. As Norman Austin explains:

\footnotetext{
${ }^{18}$ In Euripides' Hecuba, the play's eponymous heroine maintains that, if a captive who excels in beauty must be sacrificed, that should be Helen because she is "the most

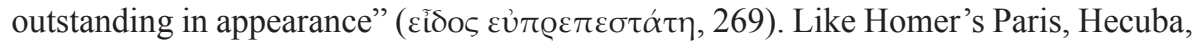
too, avoids itemizing Helen's beauty and resorts to a stereotypical statement about the attractiveness of her former daughter-in-law.
} 
If Helen is required as a witness to the covenant between the Greeks and Trojans, the plot requires also that she be witnessed. She may observe, but more important she must be observed. Her function is to be proudly displayed by the Trojans from the tower, and gazed at by the tormented Greeks, as the prize worthy of such a contest. (AUSTIN, 1994, p. 31)

Although Helen is discursively elevated to a divine status on the basis of her facial qualities, ${ }^{19}$ the male endorsers of her perfection do not focus on physiognomic details (such as eyes, mouth, and shape) or other characteristics (such as complexion, delicacy, and softness) that could convey a clearer idea of her fearful looks and validate her comparison to a goddess. Helen is situated at a prominent place - on top of Troy's Scaean Gates - and is offered to the Greeks as an object to look at, but ironically we have no sense of what she looks like.

The reluctance of the old Trojan warriors to be more specific and name the deities that Helen's image evokes is puzzling. Although the close relationship that Helen enjoys with Aphrodite - best illustrated in Iliad (III, 395-411) - encourages us to visualize her external appearance as a reflection of the physical attributes of her divine patroness (CYRINO, 2010, p. 53-56), ${ }^{20}$ Homer avoids linking his heroine explicitly to the goddess of beauty. ${ }^{21}$ Yet the poet easily does so for other, less important figures, such as Briseis (Iliad XIX, 282) and Cassandra (Iliad XXIV, 699), both of whom are said to resemble "golden" Aphrodite. ${ }^{22}$ Furthermore,

${ }^{19}$ Technically, the elders of Troy do not have full visual access to Helen's face on this particular occasion in order to liken her to a goddess. When Helen leaves her chambers, she is befittingly wrapped in her white, fine linen veil - proof of her domestication (HOMER, Iliad, III, 141).

${ }^{20}$ On the ways in which cinema has exploited this identification, see Vivante (2013) and Nikoloutsos (2015).

${ }^{21}$ The comparison is made in the Catalogue of Women (fr. 196), which reproduces a formulaic expression used for Helen's daughter Hermione in Homer (Odyssey, IV, 14). See Ormand (2014, p. 186).

${ }^{22}$ Homer's hesitation to designate Helen as Aphrodite's counterpart on earth may have something to do with the very fact that Helen symbolizes qualities that are never associated with the celestial Aphrodite: pollution and defilement. In accepting the blame for her detrimental decision to run away with Paris, Helen calls herself "bitch" three times in the Iliad (III, 180; VI, 344; VI, 356). In ancient Greek, the dog metaphor is a figure for unconstrained sexual appetite and an enormous amount of erotic freedom 
in the Iliad Helen's appeal is not distinguished by means of special vocabulary that applies to her alone as the most beautiful woman on earth. When it comes to her physical description, Homer uses the same formulaic language as that deployed for other female characters - mortal or immortal, eponymous or anonymous - and calls Helen "white-armed"

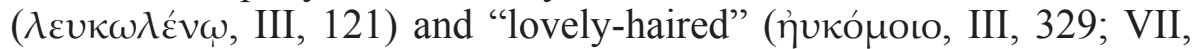
355; VIII, 82; IX, 339; XI, 369; XI, 505; XIII, 766). ${ }^{23}$ These epithets are generic markers of beauty in epic poetry and do not connote one's singularity. What is more, precisely because they apply to female figures in the poem regardless of their social status, they emphasize the referent's subjection to the ideal of domesticity. Well-arranged, orderly hair denotes a woman who knows her place, both at home and in society, and obeys the rules. White arms, in turn, denote a woman confined in the house, as opposed to the tanned arms of a lower-class woman who must work outside of the house, in the fields or the market place (MANSFIELD, 2007, p. 37). A woman bound to the oî́kos (household) is a woman devoted to her family. ${ }^{24}$

Although Book III (156-158) puts Helen on the spotlight, it casts no light on her external appearance. Helen, the Trojan elders admit, is worth fighting for, but the lethal beauty of the woman, on account of whom the Greeks and their co-patriots have suffered so many woes for ten years, remains indefinable and resists itemization. The reader/listener of the Iliad, thus, oscillates between indeterminacy in the diegetic world and a desire to synthesize Helen's figure in full in the nondiegetic space. The realism of Homer's narrative excites the mind and invites us to visualize a complete face as part of an equally attractive body, both making up a dazzling whole. Our optimism, however, to restore Helen's corporeal totality mentally, based on some clues found in the text, is undermined by the elliptical language of the passage. Although Helen emerges into

(Blondell, 2010, p. 15). As an animal that eats the dead, excrement, and its own vomit, the dog is the ultimate symbol of dirt and filthiness (Mansfield, 2007, p. 30).

${ }^{23}$ The former adjective applies to Hera (Iliad, I, 55, 195), Nausicaa (Odyssey, VII, 12), Penelope (Odyssey, XXIII, 240), and anonymous maids (Odyssey, VI, 239; XVIII, 198; XIX, 60). On the latter cliché, see Clader, (1976, p. 45-46); Ormand (2014, p. 194-195, 197).

${ }^{24}$ It is highly ironic that Homer uses such formulaic adjectives in connection with Helen since she violated all social protocols by running away with Paris and by abandoning her husband and daughter in Sparta. 
the field of vision by being put on display at the walls of Troy, her body, paradoxically, remains hidden from our sight. Like Madame Bovary in Gustave Flaubert's 1856 novel of the same title, Helen "does not have a body - of her own. Her body is the social and phantasmatic construction of the men who look at her" (BROOKS, 1993, p. 95). ${ }^{25}$

Helen's desomatization, I argue, is not unrelated to the double symbolic role that she plays in the poem in general and in this episode in Book III in particular. Helen is absent as a body but present as a metaphor. Her body is empty of flesh but full of essence. She is both an agent in the production of meaning and the locus in which the aspirations of two armies are played out. Again, Brook provides compelling instructions as to how to read Homer's lines from an intertextual perspective:

[T] he most highly elaborated symbolic structures and discursive systems no doubt ultimately derive from bodily sensations. Yet these structures and systems move us away from the body, as any use of signs must necessarily do. Representation of the body in signs endeavors to make the body present, but always within the context of its absence, since use of the linguistic sign implies the absence of the thing for which it stands. (BROOKS, 1993, p. 7-8)

Helen makes a strong physical presence in the passage above, but her body is missing from the text. Although she enters the narrative as the object of the Trojan elders' discourse, the components of her disarming beauty are banished from the poem's diction. Helen's body serves as a site of signification and provides the reason for the inscription of the story of the Trojan War. Yet this very body is cast as an empty space for male optical projections. Her legendary looks are reduced to a blank face, the details of which must be supplied by the reader/listener's imagination. In other words, Helen's semioticization results in her corporeal abstraction; the more meaning the poet bestows upon, the less flesh she possesses.

This representational strategy of the Iliad has received much praise from Edmund Burke (1729-1797), one of the most influential thinkers of the Age of the Enlightenment. In the concluding part of his

${ }^{25} \mathrm{Cf}$. Euripides' Helen, where the antithesis between óvo $\mu \alpha$ (name) and $\sigma \tilde{\omega} \mu \alpha$ (body) is deployed often $(66-69,588,1100)$ to emphasize, and problematize, the polarity between appearance (i.e., Helen as an imaginary body) and reality (i.e., Helen as a physical body). 
treatise on aesthetics entitled A Philosophical Enquiry into the Origin of Our Ideas of the Sublime and Beautiful, which he published anonymously in 1757, Burke examines the power of language to evoke images and induce emotions. Looking back to his earlier empirical thesis synopsized in the blunt formulation "A clear idea is therefore another name for a little idea" (BURKE, 1958, p. 63), he makes a distinction between verbal and visual media of representation, maintaining that, although painting does have the capacity to capture beauty, pictorial creations elicit admiration because they appeal to the sense of sight and seek to please the human eye. By contrast, poetry and rhetoric, by not being iconic, aim for sublimity, a loftier quality than beauty, and affect the intellect, thus provoking more profound responses. Drawing on Nicolas BoileauDespréaux's 1674 edition and French translation of Longinus, which became available in English in $1711,{ }^{26}$ Burke argues that a sublime work causes us to experience intense sensations, such as awe and terror, a basic precondition for which is descriptive obscurity. Whereas beautiful art attracts on account of its mimetic nature, the sublime overwhelms and often intimidates because it cannot be fully apprehended. Its markers include, inter alia, darkness, infinity, and indistinctness (BURKE, 1958, p. 57-87). ${ }^{27}$ To illustrate his point, Burke quotes the above excerpt from the Iliad from the original, as well as in Alexander Pope's translation, and notes about Helen:

\begin{abstract}
Here is not one word said of the particulars of her beauty; no thing which can in the least help us to any precise idea of her person; but yet we are much more touched by this manner of mentioning her than by these long and labored descriptions of Helen, whether handed down by tradition, or formed by fancy.... In reality poetry and rhetoric do not succeed in exact description so well as painting does; their business is to affect rather by sympathy than imitation; to display rather the effect of things on the mind of the speaker, or of others, than to present a clear idea of the things themselves.
\end{abstract}

\footnotetext{
${ }^{26}$ On the way Burke (mis)uses quotations from Longinus in the Enquiry, see Ryan (2012).

${ }^{27}$ For an analysis of Burke's theory on language and the sublime, see Boulton's introduction to his 1958 edition of the Enquiry, esp. p. lxxvi-lxxxi, as well as Shaw (2006, p. 48-63); Norman (2013, p. 26-27); Bromwich (2014, p. 84-88). On Burke and Homeric ekphrasis, see Becker (1995, p. 11-13).
} 
Burke responds to the view that clarity and precision are the principal qualities of the arts, and although he does admit that painting is more effective than poetry and rhetoric in this vein, he uses Helen's vague depiction to exemplify his argument that words can prompt thoughts and feelings without necessarily linking such cerebral reactions with a concrete and solid image. To Burke, the verbal is superior to the visual because it excites the mind and turns the reader/listener into a "viewer," inviting us to fill in the lacunae in meaning with the eyes of our imagination.

The Iliad, as Burke lucidly explains, has bequeathed us with a Helen whose facial features are to be defined by Homer's aftercomers. In post-Homeric poetry, however, the representation of Helen's beauty resists closure and standardization (MAGUIRE, 2009, p. 37). Not only is there not consistency in the way she is imagined. Greek authors also use formulaic language and portray her according to generic conventions, denying her individuality. For example, in the Catalogue of Women, Helen

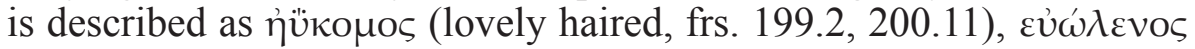

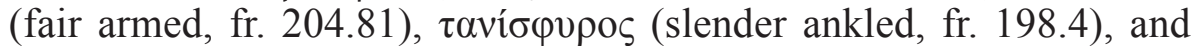
perhaps $\kappa v \alpha \nu \tilde{\omega} \pi \iota \varsigma$ (dark eyed, fr. 196.8). These are all stereotypical epithets of female beauty appropriated from the linguistic register of epic poetry (ORMAND, 2014, p. 181-202). In Sappho (Lobel-Page $23=$ Diehl 35 ) and Ibycus (282a.5 PMG), Helen receives the characterization $\xi \alpha v \theta \eta$ (tawny haired). Given that in the Iliad the adjective applies to deities and members of the Greek military elite, we are prompted to understand its use in lyric poetry as a designation of Helen's special status rather than as a mere physical trait with no symbolic value. ${ }^{28}$ The fascination with Helen's hair - after all, hair is a major component of a woman's beauty - continues well into the classical period. In Euripides' play of the same title, Helen, after she is recognized by Menelaus and the two are reunited, devises a plan so that they will escape from Egypt: she will confirm to the local King Theoclymenus the rumor about her husband's death and will

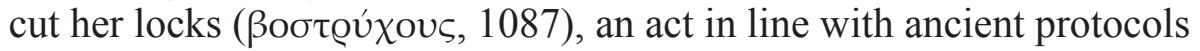

\footnotetext{
${ }^{28}$ The epithet has been misunderstood in cinema, resulting in Helen's frequent casting as blonde. See Vivante (2013, p. 25-26). On Helen's representation as blonde in the western literary tradition, see Maguire (2009, p. 214).
} 
of mourning. ${ }^{29}$ Long curly hair is not a unique attribute of Helen, but one that she shares with goddesses and other mythic heroines in Greek literature. ${ }^{30}$

As opposed to Homer's epic, post-Iliadic accounts of Helen are characterized by specificity and variety. In addition, poets of the archaic and classical period do not focus on Helen's body in its entirety, but describe it in parts, which are used metonymically to convey the attraction of the fragmented whole. As Brooks notes about Emma Bovary's depiction in Flaubert's novel:

Descriptions tend toward the metonymical, accumulating details of the body and especially of her dress and accessories. Emma tends to become a fetishized object, or rather, an object that is never seen whole because her accessory details become fetishes, arresting attention along the way. (BROOKS, 1993, p. 91)

Similarly, Helen's body fragments found in post-Homeric poetry are not sufficient to allow the reader to synthesize a complete, coherent image. They are peripheral physical details (hair, arms, and ankles) that form a circle around her erogenous zones, which are precluded from the diegesis when Helen is cast as an object of desire placed in the field of honor and female virtue. ${ }^{31}$ There seems to be a blank space in the middle of Helen's poetic body, which must be given material form, when she is transferred from the page onto canvas, the silver screen, or other visual media.

${ }^{29}$ Blondell (2013, p. 214) notes that in so doing Helen also appears to adhere to the Spartan wedding customs (as suits her pending remarriage to Menelaus upon escape from Egypt), according to which the bride cut her hair short.

${ }^{30}$ For examples from epic and tragedy, see Maguire (2009, p. 214).

${ }^{31}$ In Euripides' Andromache (627-631) - which is parodied in Aristophanes' Lysistrata (155-156) - the sight of Helen's naked breasts causes Menelaus to drop his sword and spare her life when the Trojan War ends. In this passage, Helen is divested of dignity and self-respect. Peleus underscores her disgrace by calling her a "traitorous bitch" ( $\pi \rho 0 \delta$ ó $\tau v ~ \kappa v ́ v \alpha)$. This myth probably provided the basis for the story of the Athenian courtesan Phryne who uncovered her breasts at court (McClure, 1999, p. 189). 


\section{Compromising Helen}

The visual and performing arts cannot afford to be as elusive as literature often is. Resurrecting Helen on the big screen requires an actress with iconic beauty who will convince modern audiences of her power to lead two armies to war for her sake. ${ }^{32}$ This is an immense challenge for a Hollywood studio. An article published in the online version of the U.S. magazine Variety on 24 February 2003, about two months before the German director Wolfgang Petersen started filming the blockbuster Troy in Malta, describes the quest for the actress who would be cast as Helen as follows:

Casting director Lucinda Syson held a worldwide search for Helen of Troy; Petersen said he's close to choosing a newcomer for the role. "She has to be believable as the face that launched 1,000 ships and caused the Greeks to go against Troy," said Petersen. "She has to be that beautiful." ${ }^{33}$

The casting agency's global hunt for the first cinematic Helen of the twenty-first century spanned several months, reportedly yielding a list of three thousand names. According to an article published in the British tabloid The Sunday Mirror on 13 April 2003 under the punning title "I'll Troy my Best" (subtitled: "Unknown Model Beats Stars to Play Beauty Helen"), Julia Roberts, Jennifer Aniston, Kate Winslet, and Nicole Kidman were among the international celebrities who were considered for the part during the mammoth search before Petersen decided to award

\footnotetext{
32 The ancient Helen was more than just a pretty face. An article published in the online magazine Slate on 8 January 2003 under the title "The Many Faces of Helen" uses the film Troy (2004) as an example to emphasize the lack of agency in Helen's cinematic recreations: “After months of searching for a worthy Helen, Troy's producers chose Diane Kruger, a relatively unknown German actress who is undeniably goodlooking. But when you see her face in the trailer, or wheezing by on the side of a bus, the inevitable feeling is one of letdown. Kruger is blond and pretty, but unremarkable - she'd look at home in an ad for Herbal Essences shampoo. Her face, one suspects, could launch three ships, maybe four. (Some wag once coined a term for the amount of physical beauty it takes to launch one ship: a milliHelen.) Looking at Kruger it's hard not to think, "They fought the Trojan War for this?" (http://www.slate.com/articles/ arts/culturebox/2003/01/the-many-faces-of-helen.html, last accessed January 2015). ${ }^{33}$ Quoted from http://variety.com/2003/film/news/director-firms-troy-shoot-1117881153 (last accessed January 2015).
} 
it to his co-patriot, the German top fashion model Diane Kruger. ${ }^{34}$ To the extent that this information is accurate, it conveys a desire of the studios that produced the film to cast a modern icon of beauty in the role of an ancient icon of beauty, a Hollywood queen as the queen of Sparta. ${ }^{35}$ In other words, it conveys the desire to ensure high revenues by casting as Helen a face with international appeal that would attract viewers.

Since ancient Greek poetry does not constrain the reader's imagination, asking us to picture the heroine of Homer's epic in a specific way, the flesh that Helen is given on the big screen is made appealing to modern audiences by incorporating contemporary stereotypes of beauty and sexuality. This adaptation of the past to the aesthetic ideals of the present finds a parallel in an anecdote narrated by Cicero in De inventione. Rome's most illustrious orator opens Book 2 of his treatise with a story about Helen's portrayal on canvas. The citizens of Croton, a prosperous Greek colony in the region of Bruttium in southern Italy, hired at public expense the painter Zeuxis in order to decorate the interior of a temple dedicated to Juno. ${ }^{36}$ After completing several panels, the famous artist expressed the desire to include a portrait of Helen among the paintings. To draw inspiration, Zeuxis requested that some of the local girls audition. The Crotoniates took the painter to the palaestra (wrestling school), where a group of handsome boys was training, and proudly stated that the sisters of those youths possessed equally superb looks. Zeuxis immediately asked them to summon the most beautiful of their virgins in order to choose a model. A public decree was issued, calling all the maidens of the city to gather at a place where the celebrated artist would make his selection, as the contenders would parade in front of him. Knowing that it would be impossible to find all the components of ideal beauty in a single woman, since nature does not grant absolute perfection to every part of one's body, Zeuxis chose five girls instead of one and combined their best features into a composite portrait of the mythical Helen.

\footnotetext{
${ }^{34}$ Quoted from http://www.compleatseanbean.com/troy-press23.html (last accessed January 2015).

${ }^{35}$ On this tendency in Hollywood royal portraits, see Ford and Mitchell (2009, p. 3).

${ }^{36}$ Pliny (Historia Naturalis, 35.64) connects the story with the temple of Lacinian Juno, which he erroneously places in another Greek colony in Sicily, Akragas (Latin: Agrigentum). The temple lay approximately six miles outside of Croton. Dionysius of Halicarnassus (De imitatione, 31.1) agrees with Cicero on the name of the city, but does not specify that the painting of Helen was commissioned for display at a religious space.
} 


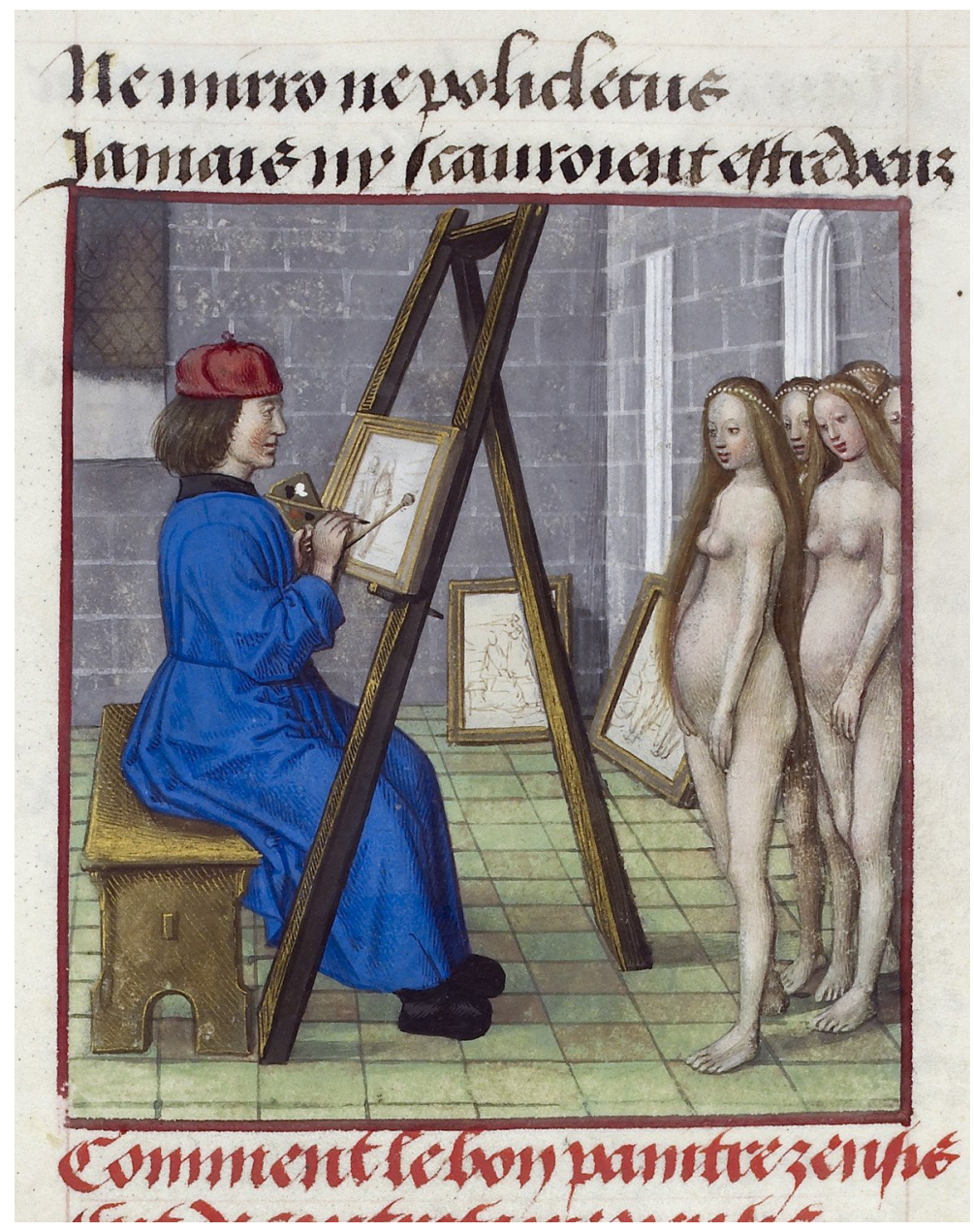

FIGURE 2: Zeuxis and Nude Models (c. 1490 - c. 1500). Column miniature in color and gold. Credit: The Harley Collection (4425, f. 142), (C) The British Library, Catalogue of Illuminated Manuscripts.

As in modern cinematic recreations of Helen, Zeuxis, too, exercised artistic license and adapted Helen's portrait to its contemporary context. Painting Helen's image for Juno's sanctuary does not seem to make much sense in the first place. Paris turned down Hera and offered the apple to Aphrodite, judging her to be the most beautiful on Olympus. As a result, the jealous goddess, along with Athena who was also rejected by 
Paris, took the side of the Greeks during the Trojan War. Seeking revenge for the offense against her, Hera facilitated the bloodletting conducted in Helen's name. Furthermore, Hera, like her Roman counterpart Juno, is the goddess of marriage and childbirth, and presides over the sacred institution of family. Helen got married three times in total: first to Menelaus, then to Paris, and, after Paris was killed, to his brother Deiphobus before she went back to first husband - not out of love, but because she had no alternative. She also gave birth to a daughter named Hermione through Menelaus. This, however, hardly seems to justify the inclusion of her image in Juno's temple, for by means of her elopement with Paris Helen defiled the institution of family.

Zeuxis erases Helen's infamous past by creating a picture of her that, since it was modeled on virgin girls from the city of Croton, sought to

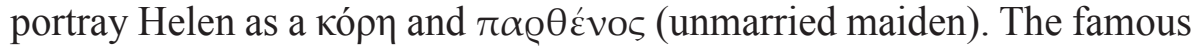
painter, thus, absolved Helen of the negative image that haunts her in most of her literary representations, that is, that of the adulterous wife and cruel mother who abandoned her husband and only daughter to run away with a foreign man, thereby igniting the longest and deadliest war in all classical myth. Zeuxis' goal was to exalt and idolize his pictorial object, for virginity connotes such highly valued aesthetic and moral qualities as purity, innocence, and self-restraint ( $\left.\sigma \omega \varphi \rho \sigma^{\prime} v \eta\right)$ that Helen is traditionally denied in ancient accounts. Such an idealized yet fragmentary portrayal of Helen fitted perfectly the religious space for which it was commissioned. In other words, Zeuxis sought to portray Helen as a marriageable girl whose image would captivate the visitor of Juno's temple in the same way Helen charmed Theseus with her beauty in Isocrates' Encomium (18):

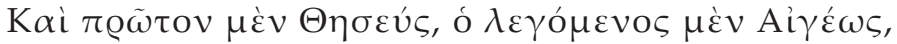

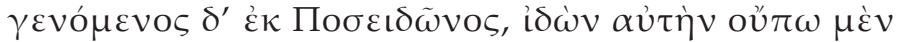

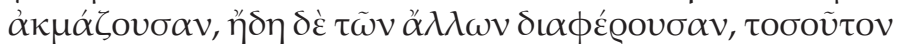

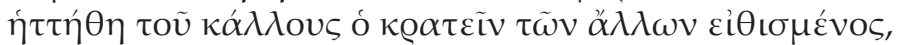

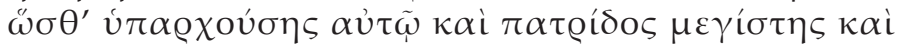

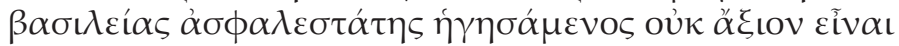

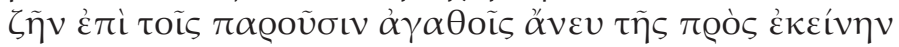

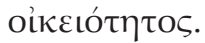

In the first place, Theseus, the reputed son of Aegeus, but in reality the offspring of Poseidon, seeing her [Helen] not as yet in her full bloom, but already surpassing other maidens, was defeated by her 
beauty to such an extent that he, who was accustomed to subdue others, although possessing both the most glorious country and the most secure kingdom, thought life was not worth living with the present blessings unless he enjoyed some intimacy with her.

The myth of Zeuxis is one of the many examples from antiquity, which show that ancient artists did not feel an obligation to be faithful to, and reproduce all the particulars of, their source texts. Alternative versions of antiquity are attested throughout classical antiquity. For example, tragedy, the popular culture of fifth century Athens, undermines the idea of a canonical story with fixed details. Some of the surviving plays preserve different, and sometimes even contradictory, versions of the same myth. Helen is a symptom of the genre's freedom to revise the past on occasion. In The Trojan Women, produced in 415 BC, Euripides places Helen among the captives of the war and Menelaus has to make the tough decision of whether to kill or spare her life. In Helen, staged three years later, the same author subscribes to a different literary tradition and writes that Helen never went to Troy. The real Helen was whisked away by the gods to Egypt and Paris took with him an effigy ( $\left.\varepsilon^{\prime \prime} \delta \omega \lambda o v\right)$.

Recreations of the ancient world are always placed at the service of their creators' artistic and ideological goals, disseminating a partial, subjective, and therefore a distorted version of the classical past. This is precisely Cicero's point in narrating Zeuxis' myth in the proem of Book 2 of De Inventione. Cicero unearths the legend of Zeuxis from the realm of the visual arts to legitimize his own eclectic style in composing a textbook about public speaking. In writing a manual on rhetoric, which was in fact a critical rewriting of persuasion techniques retrieved from the work of Athenian orators, Cicero did not seek to reproduce every single trope. Instead, he delivered to his Roman readers a synthesis of material that he deemed to be relevant. As he explains, he did not set before him a single rhetorical model with the aim of reproducing every aspect of it. After collecting all previous works on the subject in one place, he excerpted from each author whatever seemed to have the highest didactic value, presenting his Roman readers with an anthology of the best persuasion techniques found in past literature. Although they occupy different representational spheres, painting and writing, as ancient Rome's most illustrious orator seems to suggest, are parallel activities in terms of both aim (i.e., to influence) and mode of data integration (i.e., 
selective, fragmentary). ${ }^{37}$ Simply put, Cicero narrates the story of Zeuxis because he uses Helen's fragmented corpus as a metaphor for producing his own rhetorical corpus.

As a modern technology of representation, cinema extends the ancient project of reviving the past in a highly eclectic manner and refashions Helen according to modern stereotypes and ideologies. Hollywood filmmakers have sought to standardize the image of Homer's heroine by portraying her as a young woman trapped, until her salvation by the handsome Trojan prince Paris, in an unhappy marriage with a violent and power-hungry husband who is her senior by several decades (NISBET, 2006, p. 33; BERTI; GARCIA MORCILLO, 2008, p. 16). As with Zeuxis' portrait, so, too, the Helen of the big screen is denied the role of the mother that women in antiquity were expected to assume after marriage, and bears children neither to Menelaus nor to Paris. Her lack of fecundity leaves her physical beauty, the primary constituent of Helen's identity, unimpaired and raises no questions about her age, creating an illusion of virginal availability (BLONDEL, 2013, p. 48). As Martin Winkler (2009, p. 220-221) points out: "Entrapped in a loveless marriage, she can be presented as a woman almost untouched despite her extraordinary beauty and allure.... Although married, she is innocent of all emotional attachments and ignorant of the power of love." Unspoiled by childbirth, Helen is cast as a trophy wife, ready to be claimed by Paris and begin a new life with him. Admittedly, this Helen does not have much to do with her ancient counterpart, but she is definitely one that speaks to the modern viewers on a variety of different levels. This way of bringing Helen to life on screen, canvas, or other visual media must be judged not in terms of how well she corresponds to existing sources, but according to the variety of ways in which Helen is remodeled to suit the ideologies and discourses of the time of her resurrection. ${ }^{38}$

\footnotetext{
${ }^{37}$ For an analysis of Cicero's homology from a literary and philosophical perspective, see Martins (2013).

${ }^{38}$ I am most grateful to Professor Maria Cecília de Miranda Nogueira Coelho for the invitation to give a talk on Helen at the Federal University of Minas Gerais in October 2013, from which this paper emerged. Subsequent discussions with her helped give shape to many of the views presented here. I also wish to thank Saint Joseph's University for covering the copyright cost of the first illustration included in this article.
} 


\section{References}

AUSTIN, N. Helen of Troy and her shameless phantom. Ithaca: Cornell University Press, 1994.

BARKER, F. The tremulous private body: essays on subjection. Ann Arbor: The University of Michigan Press, 1995.

BARTON, R. Hedy Lamarr: the most beautiful woman in film. Lexington: The University Press of Kentucky, 2010.

BECKER, A. S. The shield of Achilles and the poetics of Ekphrasis (Greek Studies: Interdisciplinary Approaches). Lanham, MA: Rowman \& Little eld Publishers, 1995

BERTI, I.; GARCÍA MORCILLO, M. Introduction: Does Greece - and the cinema - need a new Alexander? In: BERTI, I.; GARCÍA MORCILLO, M. (Ed.). Hellas on screen: cinematic receptions of ancient history, literature and myth. Stuttgart: Franz Steiner Verlag, 2008. p. 9-20. BLONDELL, R. "Bitch that I Am": self-blame and self-assertion in the Iliad. Transactions of the American Philological Association, Baltimore, v. 140, n.1, p. 1-32, 2010.

BLONDELL, R. Helen of Troy: beauty, myth, devastation. Oxford: Oxford University Press, 2013.

BROMWICH, D. The intellectual life of Edmund Burke: from the sublime and beautiful to American independence. Cambridge, MA: The Belknap Press of Harvard University Press, 2014.

BROOKS, P. Body work: objects of desire in modern narrative. Cambridge, MA: Harvard University Press, 1993.

BURKE, E. A Philosophical enquiry into the origin of our ideas of the sublime and beautiful. Edited with Introduction and Notes by James T. Boulton. New York: Columbia University Press, 1958.

CLADER, L. L. Helen: the evolution from divine to heroic in Greek epic tradition. Leiden: Brill, 1976.

CYRINO, M. S. Aphrodite (Gods and Heroes of the Ancient World). New York: Routledge, 2010. 
212 Nuntius Antiquus, Belo Horizonte, v. 12, n. 1, p. 187-213, 2016

EDMUNDS, L. Stealing Helen: the myth of the abducted wife in comparative perspective. Princeton: Princeton University Press, 2015.

ELDRIDGE, D. Hollywood's history films. New York: I.B. Tauris, 2006.

FORD, E.; MITCHELL, D. C. Royal portraits in Hollywood: filming the lives of queens. Lexington: The University Press of Kentucky, 2009.

FULKERSON, L. The Ovidian heroine as author: reading, writing, and community in the Heroides. Cambridge: Cambridge University Press, 2005.

HALL, E. Inventing the barbarian: Greek self-definition through tragedy. Oxford: Oxford University Press, 1989.

ISENBERG, N. Edgar G. Ulmer: a fimmaker at the margins. Berkeley and Los Angeles: University of California Press, 2014.

KONSTAN, D. Beauty: the fortunes of an ancient Greek idea. Oxford: Oxford University Press, 2014.

KROHN, B. The naked filmmaker. In: HERZOGENRATH, B. (Ed.). The films of Edgar G. Ulmer. Lanham, MD: Scarecrow Press, 2009. p. 175-192.

LAMARR, H. Ecstasy and me: my life as a woman. New York: Bartholomew House, 1966.

MAGUIRE, L. Helen of Troy: from Homer to Hollywood. Malden, MA: Wiley-Blackwell, 2009.

MANSFIELD, E. C. Too beautiful to picture: Zeuxis, myth, and mimesis. Minneapolis: University of Minnesota Press, 2007.

MARTINS, P. Constructing Cicero. Nuntius Antiquus, Belo Horizonte, v. 9, n. 2, p. 221-237, 2013.

MCCLURE, L. Spoken like a woman: speech and gender in Athenian drama. Princeton: Princeton University Press, 1999.

NEGRA, D. Off-White Hollywood: American culture and ethnic female stardom. New York: Routledge, 2001.

NIKOLOUTSOS, K. P. From text to screen: celluloid Helens and female stardom in the 1950s. The Cambridge Classical Journal, Cambridge, v. 61, p. 70-90, 2015. 
NISBET, G. Ancient Greece in film and popular culture. Exeter: Bristol Phoenix Press, 2006.

NORMAN, J. Edmund Burke: the first conservative. New York: Basic Books, 2013.

ORMAND, K. The Hesiodic catalogue of women and archaic Greece. Cambridge: Cambridge University Press, 2014.

PALMER, A. P. Ovidi Nasonis Heroides. Final editing by L. Purser. Oxford: Oxford University Press, 1898.

RYAN, C. Burke's classical heritage: playing games with Longinus. In: VERMEIR, K.; DECKARD, M. F. (Ed.). The science of sensibility: reading Burke's philosophical enquiry. New York: Springer, 2012. p. 225-245. (International Archives of the History of Ideas, v. 206).

SCODEL, R. Epic framework: self-representation and social interaction in Homer. Swansea: The Classical Press of Wales, 2008.

SHAW, P. The sublime. New York: Routledge, 2006.

SHEARER, S. M. Beautiful: the life of Hedy Lamarr. Forwarded by Robert Osborne. New York: St. Martin's Press, 2010.

VIVANTE, B. Gazing at Helen: Helen as Polysemous Icon in Robert Wise's Helen of Troy and Michael Cacoyannis' The Trojan Women. In: NIKOLOUTSOS, K. P. (Ed.). Ancient Greek women in film. Oxford: Oxford University Press, 2013. p. 19-50.

WINKLER, M. M. Cinema and classical texts: Apollo's new light. Cambridge: Cambridge University Press, 2009.

ZIOGAS, I. Ovid and Hesiod: the metamorphosis of the catalogue of women. Cambridge: Cambridge University Press, 2013. 